\title{
THE ROLE OF THE ASEAN SUMMIT IN THE ASEAN ECONOMIC DISPUTE SETTLEMENT
}

\author{
Intan Soeparna \\ International Law Department, Faculty of Law, Universitas Airlangga, \\ Campus B, Jl. Dharmawangsa Dalam Selatan Surabaya, Indonesia 60286 \\ intan@fh.unair.ac.id
}

Received: $01^{\text {st }}$ October $2021 /$ Revised: $20^{\text {th }}$ October 2021/ Accepted: $01^{\text {st }}$ November 2021

How to Cite: Soeparna, I. (2021). The role of the ASEAN Summit in the ASEAN economic dispute settlement. Journal of ASEAN Studies, 9(2), 101-116.

https:/doi.org/10.21512/jas.v9i2.7771

\begin{abstract}
Like the World Trade Organization (WTO) Dispute Settlement Mechanism, the Association of South-East Asian Nations Enhanced Dispute Settlement Mechanism (ASEAN EDSM) recognizes trade countermeasures in the event of non-compliance with rulings made by the Panel and Appellate Body. However, the injured party sometimes has to deal with stumbling blocks in requesting an authorized trade countermeasure. The pitfall highlights the consequences if the dispute is unresolved. Meanwhile, ASEAN recognizes a procedure to allow the disputant parties to render unresolved disputes to the ASEAN Summit according to Article 26 of the ASEAN Charter. Moreover, if the non-implementation of the ASEAN dispute settlement decision affects the injured party, this party can submit the issue to the ASEAN Summit according to Article 27(2) of the ASEAN Charter. This research investigates whether the role of the ASEAN Summit can be a solution for the postadjudication issue in the ASEAN EDSM. The research methods consist of a literature review and close reading of the Article 26 and 27 of the ASEAN Charter. The result shows that the intervention of the ASEAN Summit to the postadjudication of ASEAN EDSM is likely to apply political solutions that would, in turn, make legal decisions subject to politically driven scrutiny. However, ASEAN commits that any economic disputes must be resolved to ensure economic stability in the ASEAN.
\end{abstract}

Keywords: ASEAN Summit, ASEAN dispute settlement mechanism, unresolved disputes 


\section{INTRODUCTION}

The creation of the ASEAN Enhanced Dispute Settlement Mechanism (EDSM) is intended to ensure expeditious and legally binding resolutions of economic disputes among ASEAN members. However, since it came into force in 2004, the mechanism has never been invoked and so has never been tested. Many scholars remain doubtful that ASEAN Members will use the ASEAN EDSM (Limenta, 2017; Ewing-Chow \& Yusran, 2018; Beckman, et al., 2016). Nonetheless, although it has never been utilized, an economic dispute mechanism is essential for implementing ASEAN Economic Agreements. ASEAN requires a "rules-based" process to ensure the viability of ASEAN economic integration. Thus, the ASEAN EDSM is expected to reinforce ASEAN's legitimacy as a vehicle to bring about predictable, transparent, centralized, and rules-based dispute settlements.

At the $51^{\text {st }}$ ASEAN Economic Ministers' (AEM) meeting on September 6, 2019, an agreement was reached to replace the 2004 Protocol on the ASEAN Enhanced Dispute Settlement Mechanism. ${ }^{1}$ Given the importance of regional dispute settlement, the completion of the ASEAN EDSM 2019 represents a significant change from the existing ASEAN EDSM 2004. ASEAN Members are willing to reconstruct the mechanism so that it is more expeditious and transparent. Some additional provisions include the procedure of the Panel, ${ }^{2}$ Special procedures for less developed countries, ${ }^{3}$ and equipping the ASEAN Secretariat with additional legal resources to assist ASEAN Members with dispute settlements. ${ }^{4}$ The efforts by AEM to improve ASEAN EDSM reflect members' prioritization of trade dispute settlements.

It is noteworthy that the ASEAN EDSM has features similar to the World Trade Organization (WTO) Dispute Settlement Mechanism (DSM). These include provisions allowing the suspension of concession or other obligations as a temporary measure in the event of non-compliance with the Panel's findings and recommendations and the Appellate Body or trade countermeasure. Unfortunately, learning from WTO DSM experiences, sometimes disputant parties encounter a stumbling block in implementing the provision of a trade countermeasure. The pitfall of trade countermeasure's authorization will lead to the dispute remaining unresolved due to the persistence of non-compliance with Panel and Appellate Body Decisions. Meanwhile, unlike WTO DSM, ASEAN recognizes a procedure to allow the disputant parties to render unresolved disputes to the ASEAN Summit according to Article 26 of the ASEAN Charter. Moreover, if the non-implementation of the ASEAN dispute settlement decision affects the injured party, this party can submit the issue to the ASEAN Summit according to Article 27(2) of the ASEAN Charter.

The main issue in this article is whether the pitfall of the implementation of trade countermeasures under the ASEAN EDSM constitute an unresolved dispute according to

At the time of writing, the revised ASEAN EDSM has not yet entered into force.

Article 8 of the ASEAN EDSM 2019 (not enforced yet).

Article 23 ASEAN EDSM 2019 (not enforced yet). Out of 10 ASEAN Member Countries, three are LowIncome Countries (LICs; Cambodia, Laos, and Myanmar). The special procedures for least-developed countries in the ASEAN EDSM may encourage recourse initiation by LICs using the ASEAN EDSM Article 22(4) ASEAN EDSM 2019 (not enforced yet). 
Article 26 of the ASEAN Charter, and whether the effect of non-compliance under the ASEAN EDSM could be submitted to the ASEAN Summit under Article 27 of the ASEAN Charter. Therefore, the research analysis focuses on the role of the ASEAN Summit in the ASEAN EDSM.

The commentary is divided into five sections. The first section consists of the background of the issue and the problem to solve in the research. The second section examines that in the event of non-compliance with the adopted Panel and Appellate Body decision under Article 16(2) ASEAN EDSM, ASEAN adopts trade countermeasure similar to the WTO DSM. The third section looks at whether Articles 26 and 27(2) of the ASEAN Charter provide solutions for unresolved disputes and the effect of non-compliance with the ASEAN EDSM Decision. This section also explains the ASEAN Summit's role in these matters, while the fourth section examines whether the ASEAN Summit can adjudicate over unresolved disputes or whether redressing a post-adjudication issue to the ASEAN Summit undermines the legitimacy of the ASEAN EDSM. The fifth section discusses the ASEAN Summit's role in the ASEAN EDSM to contain further trade imbalances between the disputant parties due to nullification and impairment of trade benefits.

\section{ANALYTICAL FRAMEWORK}

\section{Non-compliance with the Panel and Appellate Body Adopted Decision}

The purpose of the ASEAN EDSM in following the WTO DSM is to create an effective economic dispute mechanism. The prompt dispute settlement in the WTO maintains a proper balance between the disputant parties' rights and obligations. Article 16(2) of the ASEAN $\mathrm{EDSM}^{5}$ is similar to Article 22(2) of the WTO Dispute Settlement Understanding (DSU). For instance, in the event of non-implementation of the findings and recommendations of the Panel and Appellate Body, the ASEAN EDSM provides a "WTO-like" trade countermeasure.

Significantly, Article 16(2) of the ASEAN EDSM notes that any measures taken under the clause mandate the violating party to comply with the ASEAN Economic Agreements, ${ }^{6}$ noting that:

"If the Member State concerned fails to bring the measure found to be inconsistent with a covered agreement into compliance therewith or otherwise comply with the findings and recommendations of Panel and Appellate Body reports adopted by the Senior Economic Official Meeting (thereafter SEOM) within the period of sixty (60) days or the longer time period as agreed upon by the parties to the dispute as referred to in Article 15, such Member State shall, if so requested, and no later than the expiry of the period of sixty (60) days or the longer time period referred to in Article 15, enter into negotiations with any party having invoked the dispute settlement procedures, with a view to developing mutually acceptable compensation. If no satisfactory compensation has been

Article 18 under the new ASEAN EDSM 2019 (not yet in force)

ASEAN EDSM Article 1 para 1: "The rules and procedures of this Protocol shall apply to disputes brought under the consultation and dispute settlement provisions of the Agreement as well as the agreements listed in Appendix I and future ASEAN economic agreements (the covered agreements)." 
agreed within twenty (20) days after the date of expiry of the period of sixty (60) days or the longer time period as agreed upon by the parties to the dispute as referred to in Article 15, any party having invoked the dispute settlement procedures may request authorization from the SEOM to suspend the application to the Member State concerned of concessions or other obligations under the covered agreements. "7

In this article, the phrase "to suspend the application to the Member State concerned of concession or other obligations" indicates the act of countermeasure. The act of countermeasure is that Member State could suspend concession or other obligations under ASEAN Economic Agreements due to non-compliance of the violating member. Although Article 16(2) does not mention "countermeasure", the act of countermeasure is known as a form to retaliate the violating member. Moreover, the act is reminiscent of the law of the treaties.

Article 16(2) of the ASEAN EDSM focuses on three measures taken by parties to the dispute. The first measure is to end the violation committed by the violating party. In public international law, the measure is known as "cessation and non-repetition" and is generally considered the first remedy for a wrongful act. ${ }^{8}$ The second measure is negotiable compensation in the event of non-compliance. Article 36 of the International Law Commission of State Responsibility invokes compensation as a remedy that is usually denoted by a financial measure. Such compensation should cover any financially assessable damage, including loss of profits. ${ }^{9}$ However, in the WTO DSM, this compensation does not mean monetary payment, but instead refers to additional trade concessions, such as tariff reductions that the noncomplying party must institute. The purpose is to ensure that the compensation does not restrict trade but opens it up, albeit temporarily, as long as the non-complying measure remains in place (Mercurio, 2009). It is challenging for countries to find and offer a compensatory reduction of trade restrictions since such compensation requires achieving a "mutually acceptable" settlement based on the principle of "full and fair addresses" (Cho, 2004). Both parties to the dispute must determine the assessable damages. The WTO record shows how problematic it is for members to achieve voluntary and mutually acceptable compensation since this affects other stakeholders in the dispute, such as exporters, importers, and producers. It is argued that "innocent bystanders in the importing country would oppose any proposal from their government to expose them to more foreign competition as a means of compensation." (Brokers \& Van den Brock, 2006) However, since the ASEAN EDSM has never been invoked, it remains unclear whether the compensation procedure will be similar to the WTO DSM.

The third measure is the suspension of concessions or other obligations under the ASEAN Economic Agreements. The injured party can take this measure if both parties fail to

Article 16(2) of the ASEAN EDSM

Article 30, Cessation and Non-Repetition, the State responsibility for the internationally wrongful act is under an obligation, Articles on Responsibility of States for Internationally Wrongful Acts, 53 UN GAOR Supp. (No. 10) 43, U.N. Doc. A/56/83 (2001).

9 Article 36 (Compensation), (1) The State responsible for an internationally wrongful act is under an obligation to compensate for the damage caused thereby, insofar as such damage is not made good by restitution. (2) The compensation shall cover any financially assessable damage, including loss of profits insofar as it is established. 
agree on compensation, and the violation remains in place after a specific period has elapsed. It must be noted that the measure is only applied by the injured party unilaterally and temporarily after authorization from the SEOM. The trade countermeasure has been widely accepted as restitution or a retrospective form of reparation under public international law. ${ }^{10}$

In certain situations, where it might be challenging for the parties to comply with the recommendations and findings of the Panel or Appellate Body, the violating government will have no choice but to leave the breach as it is (Capucio, 2016). Likewise, when the violating party has modified the trade policy in question, but another party declines the modification, the compliance measure is not fulfilled. A useful precedent was set in a WTO dispute between Thailand and the Philippines regarding custom and fiscal measures on cigarettes (Thailand Customs and Fiscal Measures on Cigarettes from the Phillippines, 2011). In this case, Thailand modified its policy to respond to the WTO Panel and the Appellate Body's reports. However, the Philippines found that the changes were insufficient, holding that Thailand's measures were still inconsistent with the Customs Valuation Agreement and General Agreement on Trade and Tariff (GATT) 1994. Hence, in 2018, the Philippines sought recourse from the WTO Panel under Article 21(5) of the DSU concerning Thailand's alleged failure to comply with the decision of the WTO Dispute Settlement Body (DSB) (Thailand - Customs and Fiscal Measures on Cigarettes from the Philippines: Recourse to Article 21.5 of the DSU by the Philippines, 2018) and again in 2019. The Philippines identified two different measures: the charges filed by the Public Prosecutor against PMTL and the revised Notice of Assessment, neither of which had any significant changes to comply with the WTO DSB's decision (Thailand - Customs and Fiscal Measures on Cigarettes from the Philippines: Second Recourse to Article 21.5 of the DSU by the Philippines, 2019).

Thailand's experience, in this case, reflects the complexity of achieving compliance under the WTO DSM. Significantly, the compliance measure requires a government to modify or entirely withdraw the policy related to the dispute. Besides, all interested parties must accommodate the government's compliance with the rulings and recommendations. Some countries will find it difficult to modify their policies, especially if national (or political) interests are at stake (Horlick, 2002).

In the WTO legal system, a right to impose a trade countermeasure is usually done by withdrawing tariff concessions, which raises tariffs for specific imports from the violating member. Although, in general, trade countermeasures are intended to prevent continued losses for the injured party in the future and to induce compliance with the DSB Decision, implementing the measures tends to have an adverse impact on both parties. The WTO countermeasure by raising tariff levels is particularly troublesome for small developing member countries, which lack the capacity to retaliate against non-compliance members (Guzman \& Simmons, 2005: Shaffer, 2006). According to the WTO Panel in the US-Gambling Case, the economic costs of withdrawing concessions in the goods sectors would have a more significant adverse impact on a complainant developing country than on a defaulting developed

10 Article 35 (Restitution): "A state responsible for an internationally wrongful act is under an obligation to make restitution, that is, to re-establish the situation which existed before the wrongful act was committed," 
country. It is especially if the complaining party is dependent on imports from the defaulting country (United States-Measures Affecting the Cross-Border Supply of Gambling and Betting Service (US-Gambling), 2007).

Some developing countries have outlined the criticism of trade countermeasure in the WTO DSU review proposal. For example, India has outlined the tremendous imbalance of trade countermeasures between developed and developing countries. Trade imbalances have placed severe constraints on the developing countries' ability to exercise their rights under Article 22 of the WTO DSU. It would also deepen the imbalance that is already seriously undermined by the nullification and impairment of trade benefits. ${ }^{11}$ In addition, trade countermeasures through the withdrawal of tariff concessions can have detrimental effects on the economic welfare for both the non-complying and the retaliating members. The developing and least-developed countries are not likely to have the capacity to impose trade countermeasures in a way that puts real pressure on non-complying members (Shanin, 2011). Trade countermeasures are ineffective in the hands of smaller players, with small and developing countries encountering challenges when they attempt to implement effective trade countermeasures (Mavroidis, Bagwell, \& Staige, 2004; Mavroidis, 2000).

For ASEAN countries, the trade countermeasure will be more detrimental since most ASEAN firms are Small-Medium Enterprises (SMEs). The SMEs in the ASEAN represent around $88 \%$ to $99 \%$ of the enterprise population in most ASEAN Countries (The ASEAN Secretariat, 2018). Since the number of activities of the ASEAN SMEs to international trade is considered lower compared with a large firm, they often encounter resources constraints to a greater extent than large firms (Wignaraja, 2012); therefore, many ASEAN SMEs will suffer resources constraint if they have to pay a high punitive tariff to sell their products abroad.

Even if ASEAN countries attempt to do trade countermeasure, it may well damage their economies due to the high interdependency of intra-ASEAN exports and imports. ${ }^{12}$ ASEAN members with small domestic markets such as Cambodia, Laos, and Myanmar cannot impose sufficient economic losses on the bigger members due to trade countermeasure.

Despite the controversial argument of trade countermeasure, in February 2020, the Philippines made a breakthrough in a trade dispute with its ASEAN counterpart under the WTO by requesting an authorized trade countermeasure to the DSB. The request was related to Thailand's alleged failure to implement the DSB decision in a cigarettes dispute between Thailand and the Philippines. The Philippines sought authorization from the DSB to impose

\footnotetext{
${ }^{11}$ WTO Negotiation on the Dispute Settlement Understanding: Special and Differential Treatment for Developing Countries, Proposal on DSU by Cuba, Honduras, India, Indonesia, Malaysia, Pakistan, Sri Lanka, Tanzania, Zimbabwe, DSB Special Session, TN/DS/W/19, (October 9, 2002).

12 The trade-in goods in the ASEAN reached USD 2.574 billion in 2017, where intra-ASEAN trade accounted for the largest share of the ASEAN's total trade. Meanwhile, ASEAN trade in services reached USD 703 billion in 2017. Collectively, the intra-ASEAN is the largest market for ASEAN total trade since the interdependency of export and import within the intra-ASEAN is significantly high. The share of intra-ASEAN merchandise exports and imports in 2017 represented $23,5 \%$ and $22,3 \%$ of ASEAN total exports and imports, respectively (ADB, ASIAN Development Outlook 2019: Strengthening Disaster Resilience XII, 2019)
} 
countermeasures on Thailand by suspending the concession or other obligations under the WTO Covered Agreements (Thailand - Customs and Fiscal Measures on Cigarettes from the Philippines: Recourse to Article 22.2 of the DSU, 2020). However, Thailand disputed the authorization's request, not on the substantive complaint, but on the basis of procedural hurdles in the WTO DSM (Thailand - Customs and Fiscal Measures on Cigarettes from the Philippines: Communication from Thailand, 2020).

Hypothetically, if the dispute between Thailand and the Philippines had been submitted to the ASEAN EDSM, but the non-compliance with the Panel and Appellate Body decision was the same, the Philippines could request an authorized trade countermeasure to the SEOM. However, if Thailand disputed the request due to the disagreement of the level of trade countermeasure or the principle and procedures regarding the trade field to be suspended, ASEAN EDSM provides Article 16(7) that the disagreement shall be referred to arbitration. Nevertheless, learning from the WTO experience, the pitfall of the request of trade countermeasure sometimes occurred due to procedural matters. ${ }^{13}$

Unlike the WTO, the stumbling block of implementing trade countermeasure under ASEAN EDSM would constitute unresolved disputes, according to the ASEAN Charter. The unresolved disputes would also generate the effect of non-compliance with ASEAN EDSM's judicial decision. This would invoke Articles 26 and 27 of the ASEAN Charter as Shimizu (Shimizu, 2011) posited that Article 26 of the ASEAN Charter is important for ASEAN's economic dispute settlement.

\section{RESEARCH METHODS}

The research implements a literature review methods by describing what has been ruled and defined as a trade countermeasure under the ASEAN EDSM. The main purpose is to provide legal analysis on the role of the ASEAN Summit in the ASEAN EDSM. The research finds the possible role of the ASEAN Summit in the ASEAN EDSM by analyzing and close reading of the Article 26 and 27 of ASEAN Charter.

\footnotetext{
${ }^{13}$ For example, when Indonesia sought authorization from the WTO DSB to impose countermeasure against the United States due to non-compliance with this country over the Appellate Body Decision on the clove cigarette case, the European Union, as a third party, challenged the request. The European Union claimed that Indonesia disregards the ongoing compliance by the United States. Moreover, the European Union opposed Indonesia's decision to exclude the European Union as a third party in the arbitration proceedings under Article 21(5) of the DSU (Indonesia - Recourse to Article 22.2. of the DSU in the U.S. - Clove Cigarettes Dispute: Request for Consultation by the E.U., 2014).
} 


\section{ANALYSIS}

\section{Are Articles 26 and 27(2) of the ASEAN Charter a Solution for Unresolved Disputes and the Effect of Non-Compliance with ASEAN EDSM's Decision?}

Article 26 of the ASEAN Charter says, "When a dispute remains unresolved, after applying the preceding provisions of this Chapter, this dispute shall be referred to the ASEAN Summit, for its decision." This provision raises three points. The first is "when a dispute remains unresolved." Referring to Article 1(e) of the Protocol to the ASEAN Charter on DSM (Protocol 2010), the definition of unresolved disputes means a dispute over the interpretation or the application of the ASEAN Charter or other ASEAN instruments that have not been resolved by mutual agreement. The meaning of "other ASEAN instruments" in this Protocol refers to all ASEAN Agreements, including ASEAN Economic Agreements. In the context of the ASEAN Economic Agreements, the term unresolved disputes must refer to the condition when the relevant ASEAN countries fail to comply with the adopted ASEAN EDSM judicial decision (Vergano, 2009). Furthermore, an unresolved dispute also refers to the condition when the injured party seeks an authorized trade countermeasure, but the request faces a stumbling block due to procedural disagreement. Accordingly, a violation and the trade impairment will persist due to the failure to request a trade countermeasure.

The second point relates to the specification "after the application of the preceding provisions of this Chapter." This clause refers to all relevant disputes settlement mechanisms under the Chapter VIII of the ASEAN Charter, such as the ASEAN Treaty of Amity and Cooperation (TAC), the ASEAN EDSM (Protocol 2004) and the ASEAN DSM (Protocol 2010). The third issue is the directive that the matter "shall be referred to the ASEAN Summit for its decision." This stipulates that the ASEAN Summit shall act as a final arbiter if a dispute remains unresolved after the parties have used all dispute settlement mechanisms available within the ASEAN framework (Tan, 2008).

The ASEAN Charter also provides a specific rule in Article 27(2) that says that "any Member State affected by non-compliance with the findings, recommendations, or decisions resulting from an ASEAN dispute settlement mechanism, may refer the matter to the ASEAN Summit for a decision." This article allows an injured party affected by non-compliance of the other party to seek recourse from the ASEAN Summit. The non-compliance can be due to the violating party failing to comply with the ASEAN EDSM's judicial decisions. Although nothing in the ASEAN Charter expressly provides specific non-compliance with an award under the ASEAN EDSM, the natural expectation is that Article 27(2) will be followed despite the absence of explicit rules (Woon, 2016). Therefore, the ASEAN Summit could act as a final de facto arbitrator and enforcer of a decision that has been reached in any ASEAN dispute settlement mechanisms, including the ASEAN EDSM (Ewing-Chow \& Yusran, 2018).

The possibility of redressing an unresolved dispute and the effect of non-compliance with ASEAN EDSM's judicial decision to the ASEAN Summit entails two different propositions. First, the ASEAN Summit could provide an avenue to seek a solution for the dispute if the specific remedies prove futile. Furthermore, the ASEAN Summit could provide 
a political solution if unresolved disputes is due to the lack of the implementation of Article 16(2) of the ASEAN EDSM. Second, since it introduces an element of political discretion, the resort to the ASEAN Summit will conversely undermine the strength and legal certainty of the ASEAN EDSM as a system based on the rule of law.

\section{The Role of the ASEAN Summit for Unresolved Disputes and the Effect of Non- Compliance with the ASEAN EDSM's Decisions}

It is noteworthy that the function of the ASEAN Summit is to make a final decision in matters referred to it by the ASEAN Ministerial Bodies or the Secretary-General, along with acting as a final arbiter for dispute and non-compliance with all the ASEAN dispute settlement decisions. The crucial principle in the ASEAN Summit's decision-making is "consultation and consensus" (Wan, 1997). Article 20 of the ASEAN Charter empowers the ASEAN Summit to maintain the consultation and consensus rule as a form of decision-making. However, when consensus cannot be reached, the Charter allows the ASEAN Summit to utilize other decisionmaking approaches (Desierto, 2011).

The alternative way set up by Article 20 is essential for the ASEAN Summit to proceed with its decision, even if one of the parties (for example, the violating party in the issue of noncompliance) refuses to reach a consensus. The ASEAN Summit will make the final decision either through consensus or other ways. Consequently, the ASEAN Summit appears to have been vested with quasi-judicial oversight due to its role as a final arbiter (Desierto, 2011). Even so, the Summit is not, in fact, a judicial body but rather a supreme policy-making body of the ASEAN that presides over the entire gamut of ASEAN institutions (Ha \& Chalermpalanupap, 2018). In any event, the ASEAN Summit will give discretion to the disputant parties to accept or decline its decision since nothing in the Charter explicitly obliges the ASEAN Members to comply with the Summit's decision.

The ASEAN Summit could act as a final arbiter and enforcer to resolve the postadjudication issue through a political solution (Ewing-Chow \& Yusran, 2018). If the Summit is acting as a final arbiter, the decision could be overriding the legal power of the ASEAN EDSM. It is worth recalling that the ASEAN Summit is a political body. Therefore, when an issue is rendered to this body, the resolution will be more political than legal. Therefore, an intervention by the ASEAN Summit in a judicial decision would tend to erode the ASEAN's credibility (Piris \& Woon, 2015) and undermine the rules-based ASEAN dispute settlement. Conversely, if the Summit is acting as an enforcer of the adopted Panel and Appellate Body's Rulings and Recommendations, it could be deemed to be extending the legal power.

There are two situations in which the ASEAN Summit is likely to seek a political solution in the event of non-compliance with ASEAN EDSM's judicial decisions. The first is when the violating member disregards the Panel and Appellate Body decision. The ASEAN leaders will discuss why the violating member is not complying with the decision and, if there is no specific reasonable reason, apply pressure to the member. The second situation is when the injured party refuses to accept the modification of the violating member's trade policy, even though the violating party has attempted to implement the judicial decisions. In that eventuality, 
the leaders will pressure the injured party to accept the modification. For these situations, the ASEAN Summit is expected to be an enforcer of the ASEAN EDSM judicial decision.

Another possible outcome is that the ASEAN Summit will seek a win-win solution. For example, if an unresolved dispute occurred due to the condition when the injured party is seeking an authorized trade countermeasure, but the request is facing a stumbling block, the Summit can act as a final arbiter. It may suggest an alternative to trade countermeasure, such as monetary compensation (ASEAN Countries had experience giving compensation to settle the dispute (Toohey, 2011). Either way, the idea behind the ASEAN Summit's role is to build a strong economic community (Phan, 2013).

Ha and Chalermpalanupap (2018) posite that "the presence and influence of the ASEAN Summit are to the effect that the parties concerned would choose a give-and-take approach and develop win-win solutions to their problems so as not to affect the ASEAN unity and credibility." For example, in 2006, when Thailand disagreed over the Malaysian import permit requirement, and Thailand maintained a $20 \%$ retaliatory import duty, the Malaysian Trade Minister downplayed the dispute as a mere interpretation and maintained the dispute as a bilateral issue at the Summit. Thus, the disagreement would not impact the significance of the ASEAN relationship (Siong, 2011).

Phan (2013) argues that in the context of unresolved dispute under Protocol 2010 if it reaches a high-level meeting among the ASEAN Members, this can have a "naming and shaming" effect, which may create pressure to comply with the adjudication's decision. However, in the context of ASEAN EDSM, the non-compliance with the ASEAN EDSM's decision would encourage trade countermeasures. Bearing this in mind, since the ASEAN countries have not determined if trade countermeasures or sanctions would be more effective than political pressure in fostering compliance, thus, when the disputant parties decide to avoid the adverse impact of trade countermeasure, perhaps they will accept a give-and-take solution.

\section{The role of the ASEAN Summit in the ASEAN EDSM is to Rebalance the Trade between Disputant Parties}

To date, it remains uncertain if ASEAN countries will use the ASEAN EDSM to settle their trade disputes. The reason is due to the ASEAN countries experiences that using nonASEAN dispute settlement mechanisms could be seen as less confrontational. In fact, the ASEAN countries rely more on other dispute settlement mechanisms such as the WTO DSM. For example, the WTO DSM allows the participation of non-ASEAN third parties to elevate the dispute settlement from an ASEAN regional dispute subject to review by ASEAN peers (Inama \& Sim, 2015; Soeparna, 2019). WTO DSM also allows the DSB that consists of nonASEAN members to make a decision regarding the authorization of trade countermeasure. Accordingly, the role of the ASEAN political body in maintaining ultimate political control over the ASEAN trade dispute settlement system will pose the most significant challenge (Puig \& Tat, 2015; Udomjitpittaya \& Fitriana, 2019). 
Reviewing the ASEAN experiences in political disputes such as territorial sovereignty, the ASEAN Summit had little influence in bilateral disputes unless the parties involved were willing to allow it (Jenne, 2017). For example, in the Sabah dispute between the Philippines and Malaysia, these countries agreed not to raise the matter in any ASEAN forum. In the same way, Indonesia and Malaysia preferred to discuss the Ambalat conflict bilaterally during the $19^{\text {th }}$ ASEAN Summit in Bali (Druce \& Baikoeni, 2016). It was probably because the ASEAN countries would have been more discomfited politically if they had ASEAN peers reviewing and determining their territories' sovereignty due to the political susceptibility of territorial issues (Sim, 2014). When a political dispute was raised in the ASEAN Summit, most ASEAN countries were reluctant to even admit to that disagreement at the meeting (Jenne, 2017). For example, when the Indonesian leader brought up the issue over the border dispute surrounding the Preah Vihear Temple between Cambodia and Thailand at the $18^{\text {th }}$ ASEAN Summit, the Summit failed to achieve an amicable solution (Chachavalpongpun, 2013). Another issue is the dispute on the South China Sea between the People's Republic of China (PRC), Taiwan and five ASEAN's Members (Indonesia, Brunei, Malaysia, Vietnam, and the Philippines). The role of the ASEAN Summit to manage this dispute has been questioned. Although the Summit has issued a Declaration on the Conduct of Parties in the South China Sea (DOC) (ASEAN, 2004), the DOC did not design to resolve the dispute but rather maintain the peace and prevent a potential conflict. Furthermore, the DOC encourages ASEAN members to conduct direct negotiations with PRC to solve the dispute. It shows that the ASEAN maintains its nonintervention principle. This principle somehow respects the territorial integrity of each member. The key strategic of this principle allows the member to resolve jurisdictional disputes bilaterally. Nevertheless, until today the South China Sea dispute is still unresolved.

An economic or trade dispute does not raise political issues such as sovereignty. Trade disputes usually involve more technical issues with a resolution to rebalance trade relations between disputant parties. Trade disagreements are more likely to have an impact on both disputant parties and ASEAN countries that are not involved. This is because the interdependency of export and import within the intra-ASEAN is significantly high, and most ASEAN trade occurs within the bloc (Asian Development Bank, 2019). Any unresolved trade disputes will eventually undermine the trade balance among the ASEAN countries. Therefore, it would not be surprising to see the pressure from other ASEAN counterparts to settle any trade disputes. For example, in the early implementation of the ASEAN Free Trade Area (AFTA), when Malaysia delayed the implementation of the automobile tariff under the Common Effective Preferential Tariff Agreement, the delay brought an outraged response from ASEAN Members such as Thailand and Indonesia. Malaysia's halting entry into AFTA by lowering its automotive tariff impeded AFTA and inhibited the automotive trade balance among the ASEAN countries. Eventually, Malaysia sought a bilateral discussion with Thailand to settle the dispute following the AFTA Framework Agreement on dispute settlement (Lau, 2006). Likewise, in the cigarettes dispute, before elevating the dispute to the WTO DSM, the Philippines Government had raised the issue first within the ASEAN. The Philippines used diplomatic ways to talk to Thailand bilaterally to avoid the tax dispute from further escalation. Unfortunately, the official meeting between these countries over the Cigarettes dispute failed to reach an amicable result. Despite the fruitless solution, the Philippines adhered to the 
principle that bilateral trade disputes in the ASEAN should be solved first within the ASEAN (“P.H. has legal options at WTO", 2016).

Understandably, an economic or trade dispute should eventually be resolved to prevent trade imbalances among ASEAN members. Learning from the previous dispute under AFTA, trade imbalance affected ASEAN economic relations. Likewise, the impact of unresolved disputes will extend to the economic players. When unresolved disputes occur due to the violating party challenges the implementation of Article 16 of ASEAN EDSM, the trade nullification or impairment still exists and deprives trade benefit of the injured parties. Furthermore, although a trade countermeasure is a last resort to induce the compliance with Panel and Appellate Body decision, its pitfall will also prolong the trade damage that occurs to the injured party. The situation will restrain the trade balance between disputant parties. Hence, the role of the ASEAN Summit in the ASEAN EDSM is expected to avoid unresolved disputes and rebalance the trade between the disputant parties. Although the role of the ASEAN Summit in the ASEAN EDSM contravenes ASEAN non-intervention's principle, the members are willing to tolerate the role of the ASEAN Summit in the economic disputes. The reason is to secure economic or trade relations among the ASEAN members. A strong economic relation within ASEAN is a major objective of the ASEAN Economic Community. Therefore, any trade dispute should be resolved to maintain economic growth in ASEAN.

\section{CONCLUSIONS}

It seems that Articles 26 and 27(2) of the ASEAN Charter do not leave alone the ASEAN Dispute Settlement Mechanism to the rule of law, since the role of the heads of states and governments as final arbiter and enforcer denies any separation of power and is incompatible with a politically neutral dispute resolution. However, the role of the ASEAN Summit in the ASEAN EDSM is to resolve the post-adjudication issue. The intention is to find a solution for the pitfall of ASEAN EDSM's mechanism. First, the role of the ASEAN Summit is to resolve the disagreement of trade countermeasure's request under Article 16 of ASEAN EDSM. The disagreement of the request will eventually lead to the dispute being unresolved. Second, unresolved disputes will cause the extended effect of non-compliance with the ASEAN EDSM decision that is trade imbalance or injury toward the economic actors. For such reason, the role of the ASEAN Summit is preferable to enforce the Panel and Appellate Body Decision, where the political will is supporting the judicial decision. Meanwhile, the act of ASEAN Summit as a final arbiter will provide an alternative solution for disputant parties. If the disputant parties decide to avoid the adverse impact of trade countermeasure, perhaps they will accept a give-and-take solution such as monetary compensation. The intervention of the ASEAN Summit to the post-adjudication of ASEAN EDSM might be seen as an advantageous measure to settle trade disputes among ASEAN members. The idea behind the role of the ASEAN Summit in the ASEAN EDSM is that the trade dispute must be resolved to retain further damage of trade.

However, unlike Protocol 2010 Annex 5 (Rules for Reference of Unresolved Disputes to the ASEAS Summit), the ASEAN EDSM does not provide a procedure to submit the post- 
adjudication issue to the ASEAN Summit. It appears that the role of ASEAN Summit as the enforcer and final arbiter in the ASEAN EDSM needs a specific mechanism. Ultimately, although Article 26 and 27(2) of the ASEAN Charter may provide political reassurance to the ASEAN Members over the post-adjudication issue from all dispute settlements available within the ASEAN framework, nothing in the Charter prescribes any mechanism enabling the function of the ASEAN Summit to the post-adjudication issues. Therefore, it is advisable that further research elaborate on the possible mechanisms to implement Article 26 and 27(2) of the ASEAN Charter to the economic disputes.

\section{ABOUT THE AUTHORS}

Intan Soeparna is associate professor at the Department of International Law, Faculty of Law, Universitas Airlangga Surabaya Indonesia. She obtains Join PhD from Vrije Brussel Universiteit and Gent Universiteit Belgium. She is teaching International Law, International Trade Law, ASEAN Law, European Union Law, Cyber Law, and Nuclear Law at the Universitas Airlangga. Her research interests include International Law, International Trade Law, and ASEAN Law.

\section{REFERENCES}

Asian Development Bank (ADB). (2019, April 12). ASIAN Development Outlook 2019: Strengthening Disaster Resilience xii. https://www.adb.org/sites/default/files/publication/492711/ado2019.pdf

ASEAN. (2004). Terms of Reference of the ASEAN-China Joint Working Group on the Implementation of the Declaration on the Conduct of Parties in the South China Sea. Retrieved October 12, 2021, from https://asean.org/terms-of-reference-of-the-aseanchina-joint-working-group-on-the-implementation-of-the-declaration-on-the-conductof-parties-in-the-south-china-sea-2/

Bagwel, K., Mavroidis, P. C., \& Staiger, R. W. (2004). The Case for Tradable Remedies in WTO Dispute Settlement. Washington DC: World Bank.

Beckman, R., Bernard, L., Pan, H., Li, T., \& Yusran, R. (2016). Promoting Compliance: The Role of Dispute Settlement and Monitoring Mechanism in ASEAN Instruments. Cambridge: Cambridge University Press.

Bronkers, M., \& Van den Brock, N. (2006). Financial compensation in the WTO: Improving remedies of the WTO dispute settlement. In D. Georgiev \& K. Van der Borght (Eds.), Reform and Development of the WTO Dispute Settlement System (p. 50). London: Cameron May. 
Capucio, C. (2016). Implementing decisions of the WTO dispute settlement in Brazil: Is there a place for transparency and participation? Revista Brasileira de Politica Internacional, 59(1), 1-16. https://doi.org/10.1590/0034-7329201600108

Chachavalpongpun, P. (2013). Thai-Cambodian conflict: The failure of ASEAN's dispute settlement mechanisms. Asian Journal of Peacebuilding, 1(1), 65-86. http://dx.doi.org/10.18588/201305.000005

Cho, S. (2004). The nature of remedies in International trade law. The University of Pittsburgh Law Review, 65, 763 - 774.

Desierto, D. A. (2011). ASEAN's constitutionalization of the International Law: Challenges to evolution under the new ASEAN Charter. Columbia Journal of Transnational Law, 49, $268-320$.

Druce, S. C. \& Baikoeni, E. Y. (2016). Circumventing conflict: The Indonesia-Malaysia Ambalat block dispute. In M. Oishi (Eds.), Contemporary Conflicts in Southeast Asia, Asia in Transition (p. 149). Singapore: Springer Science+Business.

Ewing-Chow, M. \& Yusran, R. (2018). The ASEAN trade dispute settlement mechanism. In R. Howse, E. Ruiz-Fabri, G. Ulfstein, \& M. Zang (Eds.), The Legitimacy of International Trade Court and Tribunals (p. 383). Cambridge: Cambridge University Press.

Guzman, A. T. \& Simmons, B. A. (2005). Power plays and capacity constraints: The selection of defendants in World Trade Organization disputes. Journal of Legal Studies, 34, 557 -598 .

Ha, H. T. \& Chalermpalanupap, T. (2018). The ASEAN Summit: Origin and evolution. ASEAN Matter, (2), 1.

Horlick, G. N. (2002). Problems with the compliance structure of the WTO dispute resolution process. In D. L. Kennedy, \& J. D. Southwick (Eds.), The Political Economy of International Trade Law: Essay in Honor of Robert E. Hudec (p. 636). Cambridge: Cambridge University Press.

Inama, S. \& Sim, E. W. (2015). The Foundation of the ASEAN Economic Community. Cambridge: Cambridge University Press.

Indonesia - Recourse to Article 22.2. of the DSU in the U.S. - Clove Cigarettes Dispute: Request for Consultation by the E.U. (June 19, 2014).

Jenne, N. (2017). Managing territorial disputes in Southeast Asia: Is there more than the South China Sea? Journal of Current Southeast Asian Affairs, 36(3), 35 - 61. https://doi.org/10.1177\%2F186810341703600302 
Lau, T. (2006). Distinguishing fiction from reality: The ASEAN free trade Area and implications for the Global Auto Industry. Management and Marketing Faculty Publications, 8, 1-25.

Limenta, M. (2017). WTO Retaliation: Effectiveness and Purpose. Oxford/Portland: Hart Publishing.

Mavroidis, P. C. (2000). Remedies in the WTO legal system: Between a rock and a hard place. European Journal of International Law, 11(4), 763 - 813. https://doi.org/10.1093/ejil/11.4.763

Mercurio, B. (2009). Why compensation cannot replace trade retaliation in the WTO dispute settlement understanding. World Trade Review, 8(2), 315-338. https://doi.org/10.1017/S1474745609004273

P.H. has legal options at WTO and ASEAN over cigarette tax case vs Thailand. (2016, January 24). Manila Bulletin. https://www.asiansil.org/ph-has-legal-options-at-wto-andASEAN-over-cigarette-tax-case-vs-Thailand-manila-bulletin-24-January-2016/

Phan, H. D. (2013). Towards a rules-based ASEAN: The protocol to the ASEAN Charter on dispute settlement mechanism. Arbitration Law Review, 5, 254 - 276.

Piris, J. C. \& Woon, W. (2015). Towards a Rules-Based Community: An ASEAN Legal Service. Cambridge: Cambridge University Press.

Puig, G. V. \& Tat, L. T. (2015). Problems with the ASEAN free trade area dispute settlement mechanism and solution for the ASEAN Economic Community. Journal of World Trade, 49(2), 277-308.

The ASEAN Secretariat. (2018, December 12). ASEAN Key Figures 2018. https://www.ASEANstats.org/wp-content/uploads/2018/12/ASEAN-Key-Figures2018.pdf

Shaffer, G. C. (2006). The challenges of WTO law: Strategies for developing country adaption. World Trade Review, 5(2), 177-198.

Shanin, M. (2011). WTO dispute settlement for middle-income developing country: The situation in Egypt. In G. C. Shaffer \& R. M. Ortiz (Eds.), The Dispute Settlement at the WTO: The Developing Country Experience (pp. 282-284). Cambridge: Cambridge Press University.

Shimizu, K. (2011). The ASEAN Charter and the ASEAN Economic Community. Economy Journal of Hokkaido University, 40, 73 - 87.

Sim, E. W. (2014). The outsourcing of legal and institutions by the ASEAN Economic Community. Indonesian Journal of International \& Comparative Law, 1(1), 314 - 331. 
Siong, D. C. (2011). Trade dispute settlement within ASEAN. In Y. Y. Lee (Ed.), ASEAN Matter! Reflecting on the Association of Southeast Asian Nations (p. 116). Singapore: NUS Press.

Soeparna, I. (2019). ASEAN investment dispute settlement: A challenge to the ASEAN enhanced dispute settlement mechanism. In Y. J. Ma (Ed.), Chinese (Taiwan) Yearbook of International Law and Affairs (p. 298). Leiden/Boston: Brill Nijhoff.

Tan, E. K. (2008). The ASEAN Charter as "Legs to Go Places:" Ideational norms and pragmatic legalism in community building in Southeast Asia. In Singapore Yearbook of International Law (pp. 171 - 187). Singapore: National University of Singapore.

Thailand - Customs and Fiscal Measures on Cigarettes form the Philippines: Second Recourse to Article 21.5 of the DSU by the Philippines (2019).

Thailand - Customs and Fiscal Measures on Cigarettes from the Philippines: Recourse to Article 21.5 of the DSU by the Philippines (2018).

Thailand - Customs and Fiscal Measures on Cigarettes from the Philippines: Communication from Thailand (2020).

Thailand - Customs and Fiscal Measures on Cigarettes from the Philippines: Recourse to Article 22.2 of the DSU (2020).

Thailand - Customs and Fiscal Measures on Cigarettes from the Phillippines (2011).

Toohey, L. (2011). When "failure" indicates success: Understanding trade dispute between ASEAN members. In R. P. Buckley, R. W. Hu, \& W. D. Arner (Eds.), The East Asian Economic Integration: Law, Trade and Finance (p. 165). Northampton: Edwar Elgar.

Udomjitpittaya, W. \& Fitriana, Z. M. (2019). ASEAN vs WTO DSM: Overcoming jurisdiction issues to encourage regional trade agreement's system efficacy. Yurika, 35(2), 407 428. http://dx.doi.org/10.20473/ydk.v35i2.16876

United States-Measures Affecting the Cross-Border Supply of Gambling and Betting Service (US-Gambling) (2007).

Vergano, P. R. (2009). The ASEAN Dispute Settlement Mechanism and Its Role in a RulesBAsed Community: Overview and Critical Comparison. Tokyo: ASIAN International Economic Law Network, University of Tokyo.

Wan, C. K. (1997). ASEAN in the new millennium. In C. Yue, \& m. Pacini (Eds.), ASEAN in the New ASIA: Issue \& Trends (pp. 147 - 149). Singapore: ISEAS - Yusof Ishak Institute.

Wignaraja, G. (2012). Engaging Small and Medium Enterprise in Production Network: FirmLevel Analysis of Five ASEAN Economies. Tokyo: ASIAN Development Bank Institute.

Woon, W. (2016). The ASEAN Charter. Singapore: National University Singapore Press. 